\title{
Potential impacts of different spring grazing strategies on lamb finishing in hill country
}

\author{
D.R. STEVENS, A.J. WALL and B.R. THOMPSON \\ Invermay Research Centre, AgResearch, Private Bag 50034 Mosgiel, New Zealand. \\ david.stevens@agresearch.co.nz
}

\begin{abstract}
How does the pasture cover at the beginning of lambing and the grazing strategy used in early spring influence the ability of a hill country sheep and beef farm to finish lambs? The results from an intensive pasture-mowing trial investigating three defoliation intensities (Lax, Moderate and Intense) starting from two herbage masses (1200 or $1500 \mathrm{~kg} \mathrm{DM} / \mathrm{ha}$ ) during early spring were used to provide data on potential pasture consumption and feed quality from lambing to weaning for a breeding ewe flock. Using simulation modelling, this pasture data was used to estimate the potential lamb and ewe liveweight changes from birth to weaning at each of three different stocking rates (4.5, 8 and 10.5 twin-bearing ewes/ha) that closely represented the three defoliation intensities originally studied in a mowing trial. The impacts of these early-spring herbage masses and grazing intensities/ stocking rates on subsequent feed requirements and potential lamb finishing during the later summer and autumn period in four contrasting geo-climatic regions of New Zealand were then further investigated using simulation modelling. Variations in ewe and lamb weaning weights were evident and reflected the amount of pasture available through the different grazing management approaches. For all four geoclimatic regions studied, the Intense grazing, high stocking rate strategy generally produced the greatest gross revenue per ha from lamb sales out of the three grazing strategies investigated, though not significantly greater than the moderate stocking rate in summer dry environments. However, under Intense grazing, a high pasture cover $(1500 \mathrm{~kg} \mathrm{DM} / \mathrm{ha})$, in comparison to a low pasture cover $(1200 \mathrm{~kg} \mathrm{DM} / \mathrm{ha})$ at the start of ewe lactation further improved the gross revenue received from lamb sales, especially in the Canterbury and Waikato environments but less so in the Hawke's Bay and Southland environments. These variations demonstrate how iterations based on the same starting properties impact on weaning weight of lambs and post-weaning pasture growth and/or feed quality.
\end{abstract}

Keywords: emergence, feed supply, geo-climatic regions, iteration, lactation, lamb weaning weight, pasture quality.

\section{Introduction}

Early spring is an important time when livestock are grazed continually outdoors in temperate climates. Graziers make a range of management decisions to balance the pasture supply and animal demand to achieve current and future objectives for both animal and pasture (Danckwerts \& Tainton 1993). These include altering lambing date to better match spring growth, altering stocking rate, or carrying over wintergrown feed to provide a feed buffer in spring (Parker et al. 1997). Farmers often begin lambing with low pasture covers because of these decisions. Having a pasture cover that is too high may also result in accumulating too much feed during late spring, with negative flowon effects on feed quality especially in the following summer and autumn (Litherland et al. 1999). In addition, the strategy of low pasture cover may reduce pasture growth (Hodgson \& Wade 1978) and animal performance (McCall et al. 1986) over spring.

Hill country sheep graziers in New Zealand often use a continuous grazing policy during spring, corresponding with late pregnancy and lactation. Stocking rates are chosen to match feed supply and demand in average conditions. Pasture growth in hill country can vary significantly during spring (Li et al. 2012). At this time the grazier relies on the energy reserves of the ewe to buffer shortfalls in feed supply (Stevens et al. 2011).

How does the grazier balance grazing management with pasture cover in spring? What critical factors influence the overall performance of a breeding ewe sheep flock when both the spring and late summer/ autumn feed requirements and potential animal performance are considered?

This study investigated the relative importance of pasture cover and grazing intensity during the first 4 weeks of ewe lactation on hill country lamb finishing outcomes. The resulting impacts that these early spring grazing strategies have on breeding ewe and lamb liveweight gain during lactation and on their subsequent finishing potential was investigated with scenario modelling in four contrasting geo-climatic regions of New Zealand.

\section{Materials and Methods}

An intensive pasture-mowing trial investigating three defoliation intensities (Lax, Moderate and Intense) 
starting from two herbage masses (1200 kg DM/ha or $1500 \mathrm{~kg} \mathrm{DM} / \mathrm{ha}$ ) during spring from 25 August to 7 December 2011 was conducted at the Invermay Research Centre, Mosgiel, New Zealand $\left(45.89^{\circ} \mathrm{S}\right.$; $\left.170.50^{\circ} \mathrm{E}\right)$. The three defoliation intensities were applied for the first 4 weeks of the normal breeding ewe spring lactation period. Subsequent defoliations maintained the pastures at the heights achieved after the 4 weeks, with defoliations occurring at 2-weekly intervals until the time lambs would normally be weaned (91 days of age). Details of the experiment are provided in Stevens et al. (2013). The amount of pasture that would be available for ewes and lambs was recorded in the 2011 experiment and used as the basis of the current investigation to determine the likely outcomes from grazing twin-bearing ewes and their lambs during lactation, and the follow-on effects on summer lamb finishing. A computer-spreadsheet simulation model was created to test the three defoliation strategies under the two starting pasture covers. For the simulation model, feed requirements were calculated (Agricultural and Food Research Council 1993). Lambs were considered dependent on milk until they reached 21 days of age and ewe lactation thereafter was reduced by $1 \%$ of the total lamb demand per day until weaning (following Muir et al. 2000).

During lactation, rules were required to govern ewe liveweight change. Ewes were able to lose condition, up to $10 \%$ of liveweight (considered to be equal to 1 body condition score (BCS)) consistent with both onfarm and research data (Stevens et al. 2011; Thompson et al. 1990). Liveweight loss was limited to $\leq 150 \mathrm{~g}$ /day (Geenty \& Sykes 1986) and liveweight gain limited to $\leq 100$ g/day (Rattray et al. 1987; Smeaton \& Rattray 1984). It was assumed that once ewes had begun gaining liveweight after a period of loss, they would not re-enter a liveweight loss phase, but would rather reduce lactation output (Rattray et al. 1982). A twinbearing breeding ewe flock weaning 1.75 lambs/ewe was modelled.

Lambs were able to gain weight at up to $350 \mathrm{~g} /$ day (Muir et al. 2000). Liveweight gain was reduced when the combination of ewe BCS reserves and available pasture were unable to meet feed demands. Weaning was at 91 days of age. All lambs were assumed born on the same day.

Stocking rates were chosen to closely mimic the results of the defoliation intensities used in the Invermay pasture-mowing trial (Stevens et al. 2013). The Lax grazing strategy required a low ewe stocking rate (4.5 ewes/ha), which resulted in an increase in sward height and allowed the lamb and ewe liveweight gain to increase with the high pasture cover available 4 weeks after lambing. The Moderate grazing strategy resulted in the maintenance of sward height and required the feed demand from the ewe stocking rate ( 8 ewes/ha) to equal the rate of herbage growth up to 4 weeks after lambing, but provided the opportunity to reduce cover later on. The Intense grazing strategy resulted in a reduction in sward height, using a stocking rate of 10.5 ewes/ha, and provided the opportunity to maximise ewe and lamb performance early but livestock performance declined later if feed demand exceeded supply.

Pasture energy content was assumed to be $12 \mathrm{MJME} /$ $\mathrm{kg} \mathrm{DM}$ in early spring and declined from 8 weeks postlambing to be $11.0 \mathrm{MJME} / \mathrm{kg}$ DM by weaning, reflecting the measurements taken during the original Invermay pasture-mowing trial. The modelling assumed that the decline in pasture quality during lactation was likely to be similar throughout New Zealand (Litherland et al. 2002). The pasture utilisation during early spring was based directly on the Invermay pasture-mowing trial which followed a prescribed defoliation regime. This provided a range of potential grazing options that would reflect different stocking rates and performance philosophies currently seen in hill country sheep farming.

Lambing dates were chosen for each region to equal the date when average pasture growth equalled the ewe demand for the Moderate grazing strategy (15 $\mathrm{kg} \mathrm{DM} / \mathrm{ha} /$ day) to facilitate the modelling of postweaning outcomes in four regions of contrasting geoclimatic characteristics (Table 1). The regions chosen were summer cool, moderate soil moisture deficit (Southland), summer warm, high soil moisture deficit (Canterbury), summer hot, high soil moisture deficit (Hawke's Bay) and summer hot, low soil moisture deficit (Waikato). All sites represented hill country.

Post-weaning grazing simulations were designed around the pasture growth and quality for each region that matched the 91 day weaning date represented in Table 1. Pasture growth (Figure 1a) was calculated as the average of simulations using the APSIM model (Keating et al. 2003) from climate data from 2001 to 2010 for hill country soils in the four regions and are described by Thompson (2014). Pasture quality (Figure $1 \mathrm{~b})$ for the four regions was estimated from previously reported data (Litherland et al. 2002) using Tararua as an approximation for Hawke's Bay. While there may be residual effects of the chosen spring stocking rates on

Table 1 Lambing and weaning dates for the four geoclimatic regions studied.

\begin{tabular}{lrr}
\hline Region & Lambing date & Weaning date \\
\hline Southland & $10 \mathrm{Sep}$ & $16 \mathrm{Dec}$ \\
Canterbury & $26 \mathrm{Aug}$ & $26 \mathrm{Nov}$ \\
Hawke's Bay & $19 \mathrm{Aug}$ & $18 \mathrm{Nov}$ \\
West Waikato & $29 \mathrm{July}$ & $29 \mathrm{Oct}$ \\
\hline
\end{tabular}



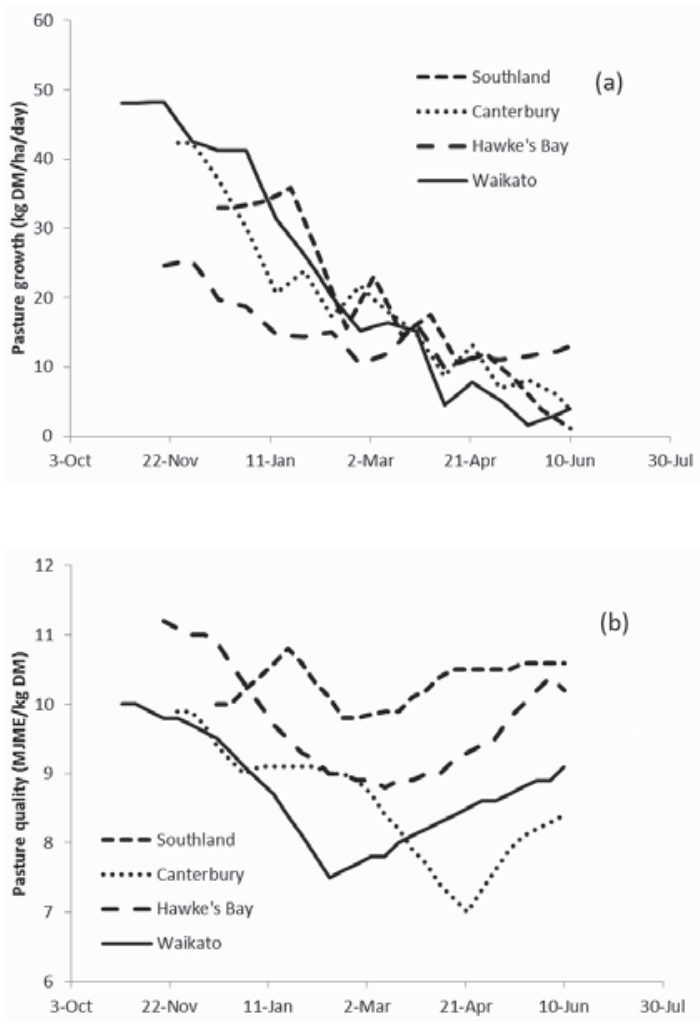

Figure 1 (a) Pasture growth estimates from long term climate records for four geo-climatic regions of New Zealand generated by the APSIM model; (b) pasture quality estimates from published data (Litherland et al. 2002) for four geo-climatic regions of New Zealand.

summer feed quality, this has not been accounted for and it is assumed that grazing management practices will ameliorate this to provide the feed quality estimated that have been used.

Separate lamb payment schedules were used for the North Island and South Island and comprised 5 years' average values of 2010 to 2014 calculated in weekly increments (Thompson 2014). Store lamb prices were calculated as a percentage of the prime price as per the Farmax relativities for each month of the year.

The summer feed requirements for the ewes were calculated to attain a target liveweight of $65 \mathrm{~kg}$ by mating. Replacement ewe lambs were removed from the lamb cohort at weaning and their requirements added to the ewe flock at a replacement rate of 33\%. Feed remaining after these targets were met was then allocated to lambs. If less feed was available than the requirement for the remaining lambs then enough lambs were sold store to reduce the feed requirement to that available. No further adjustments were made if feed was in excess of requirements. The feed requirement

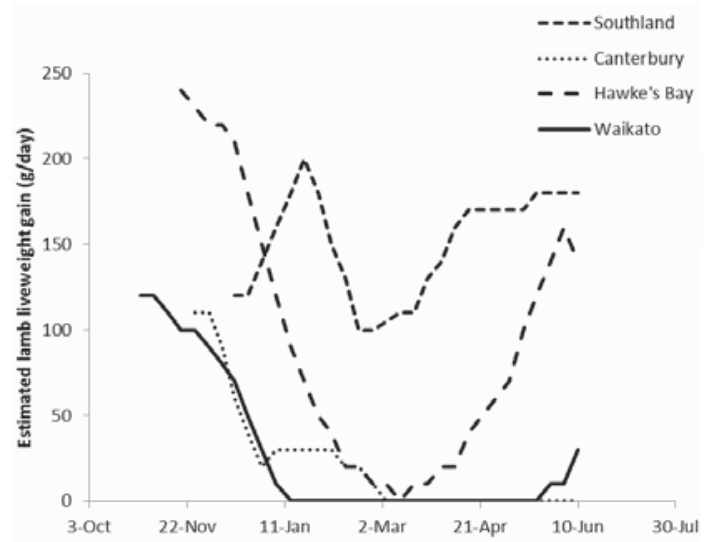

Figure 2 Estimated lamb liveweight gain from late spring weaning until early winter for four geo-climatic regions of New Zealand.

of the lambs was calculated based on the liveweight of the lamb and the predicted liveweight gain. Lamb liveweight gain (Figure 2) was predicted using a simple linear relationship between the metabolisable energy content of the pasture and growth rate. A minimum pasture ME value to achieve growth was set at 8.8 MJME/kg DM and lamb growth was estimated to be $100 \mathrm{~g} / \mathrm{MJME} / \mathrm{kg}$ DM above this following the general principles in the Q-Graze software (Woodward et al. 2000, 2001).

In the computer simulations the decision to sell lambs prime was made weekly and was calculated to include all lambs $>35 \mathrm{~kg}$ at weaning (dress out percentage $=$ $46 \%$, minimum carcase $=16.1 \mathrm{~kg}$ ) and $39 \mathrm{~kg}$ postweaning (dress out percentage $42 \%$, minimum carcase weight $=16.4 \mathrm{~kg}$ ). A normal distribution in liveweight was assumed with a standard deviation of $\pm 5 \mathrm{~kg}$.

Reported outcomes from the modelling included ewe and lamb liveweight during the lactation period, the number and carcase weight of lambs sold prime at weaning and during the post-weaning finishing period, the number and liveweight of lambs sold store, the value of lambs sold and the amount of pasture consumed during summer to achieve the finishing outcomes.

\section{Results and Discussion}

\section{Lactation period}

The amount of pasture herbage consumed per ha was lowest under Lax grazing, intermediate under Moderate grazing and greatest under Intense grazing (2120, 2430 and $2650 \mathrm{~kg} \mathrm{DM} /$ ha respectively, LSD =174). Pasture consumption was designed to closely mimic the pasture available that was measured through the different defoliation strategies in the pasture-mowing trial, and this is represented in Figure 3. Lax grazing allowed for increasing pasture consumption throughout the spring 
Table 2 Weaning outcomes and the potential lamb finishing outcomes of two pasture covers at the start of lactation and three grazing strategies during lactation in four geo-climatic regions of New Zealand.

\begin{tabular}{|c|c|c|c|c|c|c|c|}
\hline \multirow{2}{*}{\multicolumn{2}{|c|}{$\begin{array}{l}\text { Starting pasture cover at lambing } \\
\text { Grazing strategy over lambing }\end{array}$}} & \multicolumn{3}{|c|}{$1200 \mathrm{~kg} \mathrm{DM} / \mathrm{ha}$} & \multicolumn{3}{|c|}{$1500 \mathrm{~kg} \mathrm{DM} / \mathrm{ha}$} \\
\hline & & Lax & Moderate & Intense & Lax & Moderate & Intense \\
\hline \multicolumn{8}{|c|}{ Weaning Outcomes } \\
\hline & Lamb liveweight (kg/ha) & 282 & 452 & 471 & 282 & 441 & 506 \\
\hline & Number of lambs sold/ha & 3.6 & 3.3 & 0.5 & 3.6 & 2.8 & 1.0 \\
\hline & Remaining to finish/ha & 2.8 & 8.0 & 14.5 & 2.8 & 8.6 & 13.9 \\
\hline \multirow[t]{9}{*}{ Southland } & Weaning date & 16-Dec & 16-Dec & 16-Dec & 16-Dec & 16-Dec & 16-Dec \\
\hline & Average days to slaughter & 18 & 29 & 65 & 18 & 33 & 53 \\
\hline & No sold store/ha & 0.0 & 0.0 & 0.0 & 0.0 & 0.0 & 0.0 \\
\hline & Store liveweight (kg) & NA & NA & NA & NA & NA & NA \\
\hline & No sold prime/ha & 6.4 & 11.4 & 14.9 & 6.4 & 11.4 & 14.9 \\
\hline & Carcase weight $(\mathrm{kg})$ & 18.0 & 17.7 & 17.6 & 18.0 & 17.7 & 17.6 \\
\hline & Amount eaten (kg DM/ha) & 64 & 297 & 1079 & 64 & 352 & 880 \\
\hline & Store sales (\$/ha) & 0 & 0 & 0 & 0 & 0 & 0 \\
\hline & Prime sales $(\$ / \mathrm{ha})$ & 643 & 1107 & 1405 & 643 & 1102 & 1417 \\
\hline \multirow[t]{9}{*}{ Canterbury } & Weaning date & 26-Nov & 26-Nov & 26-Nov & 26-Nov & 26-Nov & 26-Nov \\
\hline & Average days to slaughter & 18 & 36 & 69 & 18 & 43 & 70 \\
\hline & No sold store/ha & 0 & 0 & 9.8 & 0 & 0 & 4.5 \\
\hline & Store liveweight (kg) & NA & NA & 29.6 & NA & NA & 31.3 \\
\hline & No sold prime/ha & 6.4 & 11.4 & 5.1 & 6.4 & 11.4 & 10.4 \\
\hline & Carcase weight $(\mathrm{kg})$ & 18.0 & 17.6 & 17.2 & 18.0 & 17.5 & 17.3 \\
\hline & Amount eaten (kg DM/ha) & 62 & 313 & 1264 & 62 & 385 & 1163 \\
\hline & Store sales (\$/ha) & 0 & 0 & 687 & 0 & 0 & 336 \\
\hline & Prime sales $(\$ / \mathrm{ha})$ & 661 & 1119 & 478 & 661 & 1103 & 981 \\
\hline \multirow[t]{9}{*}{ Hawke’s Bay } & Weaning date & 18-Nov & 18-Nov & 18-Nov & 18-Nov & 18-Nov & 18-Nov \\
\hline & Average days to slaughter & 14 & 23 & 44 & 14 & 25 & 42 \\
\hline & No sold store/ha & 0 & 0 & 8.6 & 0 & 0.6 & 8.5 \\
\hline & Store liveweight (kg) & NA & NA & 27.4 & NA & 29.5 & 29.3 \\
\hline & No sold prime/ha & 6.4 & 11.4 & 6.4 & 6.4 & 10.8 & 6.4 \\
\hline & Carcase weight $(\mathrm{kg})$ & 18.1 & 17.8 & 17.5 & 18.1 & 17.7 & 17.3 \\
\hline & Amount eaten (kg DM/ha) & 66 & 279 & 556 & 66 & 308 & 535 \\
\hline & Store sales (\$/ha) & 0 & 0 & 622 & 0 & 48 & 658 \\
\hline & Prime sales (\$/ha) & 712 & 1219 & 649 & 712 & 1146 & 653 \\
\hline \multirow[t]{9}{*}{ Waikato } & Weaning date & 29-Oct & 29-Oct & 29-Oct & 29-Oct & 29-Oct & 29-Oct \\
\hline & Average days to slaughter & 18 & 32 & 84 & 18 & 36 & 72 \\
\hline & No sold store/ha & 0 & 0 & 3.9 & 0 & 0 & 0.6 \\
\hline & Store liveweight (kg) & NA & NA & 31.2 & NA & NA & 31.7 \\
\hline & No sold prime/ha & 6.4 & 11.4 & 11.0 & 6.4 & 11.4 & 14.3 \\
\hline & Carcase weight $(\mathrm{kg})$ & 18.0 & 17.6 & 17.3 & 18.0 & 17.6 & 17.4 \\
\hline & Amount eaten (kg DM/ha) & 63 & 300 & 1441 & 63 & 360 & 1075 \\
\hline & Store sales (\$/ha) & 0 & 0 & 310 & 0 & 0 & 49 \\
\hline & Prime sales $(\$ / \mathrm{ha})$ & 720 & 1229 & 1108 & 720 & 1218 & 1466 \\
\hline
\end{tabular}


but resulted in a low lamb production per hectare due to the low stocking rate (Table 2). Further investigation of the potential for this strategy to be used for tripletbearing ewes may yield a better outcome. Pasture production may vary between the geo-climatic regions and between seasons. However, the planned start of lambing for each scenario was chosen to best match the average relative feed supply in each of those regions. Peak pasture growth in excess of the consumption of approximately $40 \mathrm{~kg} \mathrm{DM} / \mathrm{ha} /$ day has been measured in each of these environments (Radcliffe 1975; Rickard \& Radcliffe 1976; Round-Turner et al. 1976; Sithamparanathan 1979).

Moderate grazing provided similar amounts of feed regardless of whether the starting cover was 1500 or $1200 \mathrm{~kg} \mathrm{DM} /$ ha (Figure 3). This grazing strategy provided enough feed for maximum production until approximately two-thirds of the way through lactation (Figure 3). Intense grazing resulted in the highest feed consumption during early lactation (Figure 3) but this was surplus to ewe maintenance and lactation requirements and promoted potential liveweight gain in the ewes (Figure 4). A low starting cover of 1200 $\mathrm{kg} \mathrm{DM} / \mathrm{ha}$ resulted in the lowest feed availability in late lactation (Figure 3) and the lowest individual lamb weaning weights (Figure 5), even though ewe liveweights (Figure 4) were similar to those with a starting cover of $1500 \mathrm{~kg} \mathrm{DM} / \mathrm{ha}$. This reflected a low lamb feed intake. This follows the reported outcomes of competition between the ewe and the lamb when feed supply is short (Moss et al. 2009).

Ewe liveweight profiles varied throughout the lactation (Figure 4). This variation depended on the relative availability of pasture and demand from the lamb. When pasture cover was increasing an assumption was made in the computer simulation-modelling that the ewe will not increase liveweight during the first 4 weeks but will increase in liveweight if extra feed is available in the subsequent period to weaning.

Where pasture cover was being maintained in the Moderate grazing strategies there was little surplus above the lactation requirements of the stocking rate chosen. Minor variations between pasture supply and feed demand were buffered by small changes in ewe liveweight in early lactation. Liveweight loss was confined to the mid-lactation period, with ewes recovering liveweight in the latter part of lactation (Figure 4). It was assumed that once liveweight recovery begins the ewe will not re-enter a liveweight loss period, but, instead, begin to reduce lactation output if feed supply does not meet demand. This resulted in a decline in the rate of lamb liveweight gain during late lactation (Figure 5).

When pasture cover was declining under the Intense grazing strategies during lactation, the surplus pasture

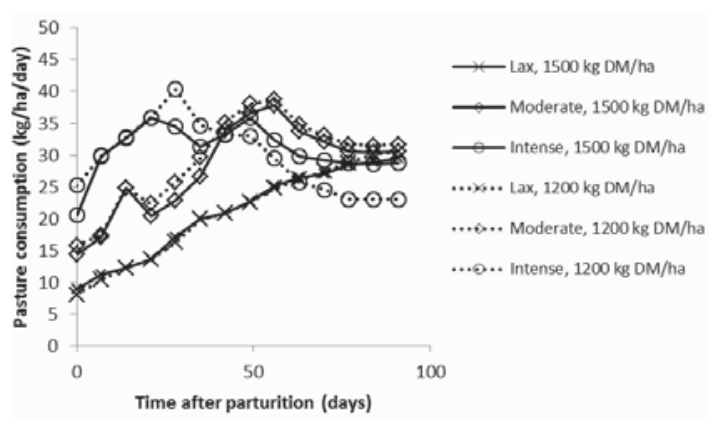

Figure 3 Pasture consumption pattern modelled using a range of grazing strategies during lactation for ewes rearing 1.75 lambs/ewe during spring.

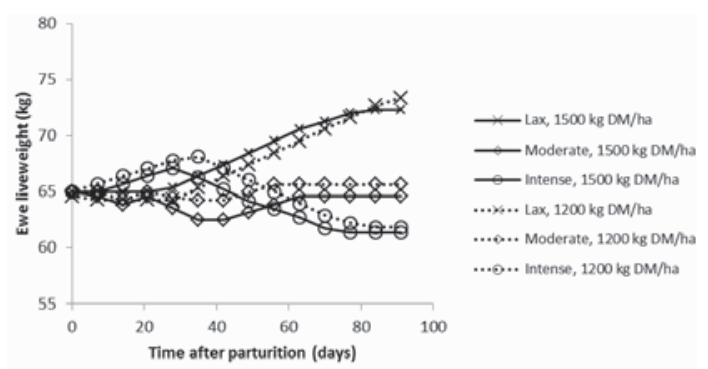

Figure 4 Liveweight of ewes over lactation under three grazing strategies (Lax, Moderate and Intense) and starting from two pre-lactation pasture covers (1200 and $1500 \mathrm{~kg} \mathrm{DM} / \mathrm{ha}$ ).

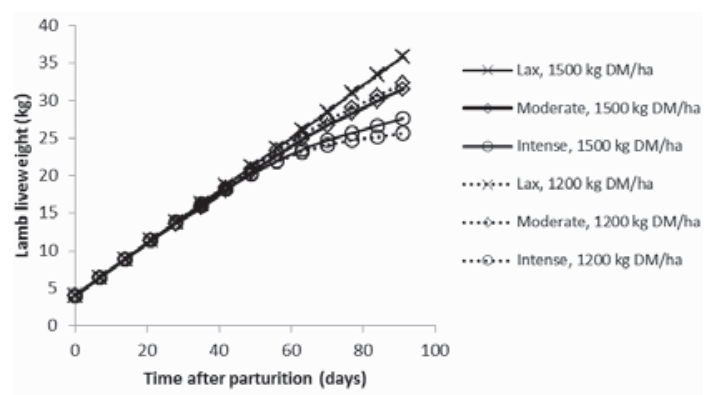

Figure 5 Pre-weaning lamb liveweights under three grazing strategies (Lax, Moderate and Intense) and starting from two pre-lactation pasture covers (1200 and $1500 \mathrm{~kg} \mathrm{DM} / \mathrm{ha})$.

eaten above maintenance and lactation requirements was stored as ewe liveweight (Figure 4). This mechanism is untested. As feed demand increased as the lambs grow, ewe liveweight was used to buffer feed supply shortages to a maximum liveweight loss of 150 $\mathrm{g} /$ day. This loss was from mid-lactation onward, and at the stocking rate chosen for the Intense grazing, was maintained for longer than under the Moderate grazing strategy, until 1 BCS was lost (Figure 4).

While these simulations are plausible, there is little evidence to test the true liveweight and body 
condition score changes that may occur at such fine time increments. Most reported research only provides condition score data at specific events such as prelambing, docking, and weaning (Everett-Hincks et al. 2013; Kenyon et al. 2004; Stevens et al. 2011). The final outcomes of ewe liveweight and lamb weaning weight are comparable with on-farm experiences (Casey et al. 2013; Stevens et al. 2011). It does appear, however, that maximum lamb weaning weight may only be achieved when ewe liveweight also has the opportunity to increase (Muir et al. 2003). Some on-farm examples are provided by lucerne grazing examples (Stevens et al. 2012, 2015).

Small variations in late lactation feeding (Figure 3) appear to have a significant effect on individual lamb weaning weights (Figure 5). This was seen in the Moderate grazing strategy with a starting pasture cover of $1500 \mathrm{~kg} \mathrm{DM} / \mathrm{ha}$. This treatment resulted in a lower individual lamb weaning weight than the Moderate grazing strategy with a starting pasture cover of 1200 $\mathrm{kg} \mathrm{DM} /$ ha (Figure 5) due to minor differences in late spring feed supply (Figure 3). The role of the buffering ability of the ewe using BCS under changing pasture supply conditions needs significantly more research before we can answer these questions to farmers' satisfaction.

The pasture cover at the start of lambing had a much smaller influence on individual lamb weaning weights than stocking rate (Figure 5). Most of the influence of stocking rate was seen during the late, rather than early, lactation period. The timing of ewe liveweight change had a greater influence on variations in individual lamb weaning weight and this again raises questions around the current understanding of short time scale variations in feed supply on ewe body reserve mobilisation for lactation.

It is important to note that in the computer simulationmodelling the variation in starting pasture cover is used to provide feed only for lactation and beyond, rather than for late pregnancy. Many farmers begin continuously grazing pasture between 7 and 28 days before lambing, resulting in the use of winter-conserved pasture cover for late pregnancy feeding rather than lactation feeding. Comparisons of the relative importance of pasture for late-pregnancy versus lactation feeding are not well described in the literature.

The relative outcomes of these grazing strategies by weaning appear to be self-evident: Lax, low stocking rate (4.5 ewes/ha) grazing leads to heavy ewes and high individual lamb weaning weight; Moderate, medium stocking rate ( 8 ewes/ha) grazing leads to maintaining ewe liveweight and moderate lamb growth rates; while, Intensive, high stocking rate (10.5 ewes/ ha) grazing leads to light ewes and lower lamb growth rates. However, there are two points of importance in the outcomes from this computer simulation-modelling of these pre-weaning grazing strategies: The first is that there is not enough reported data available to understand short time series variations in feed supply on ewe liveweight change. This has significant potential impacts on designing future pasture grazing and supply strategies, as small interventions may provide large relative increases in performance of both the ewe and the lamb. The second point is that most of the variation in individual lamb growth rates potentially occurred in late lactation. This variation has been documented before where lamb liveweight at day 30 is relatively similar between pasture supply options, but can be much greater by day 90-100 (Corner-Thomas et al. 2015; Stevens et al. 2012). Work in red deer also confirms the role of late-lactation feed supply and hind body reserves in calf weaning weight (Stevens et al. in press). These results highlight this potential cause of variation in individual lamb weaning weight and provide farmers with a focus to develop potential cost-effective interventions and mitigations to improve individual lamb weaning weights.

The ewe liveweights in Figure 4 were consistent with the modelling assumptions made and the feed supply strategies chosen. Based on these assumptions of maximum gain or loss and when that liveweight change may occur, then changes in the feed supply were reflected in the individual lamb liveweight at weaning (Figure 5). The high pasture cover (1500 kg DM/ha) at the start of ewe lactation only provided a benefit over a low starting pasture cover (1200 kg DM/ha) when ewe stocking rate was high (10.5 ewes/ha), and resulted in an extra $35 \mathrm{~kg}$ of lamb weaned per hectare (Table 2).

The importance of relatively small variations in individual lamb weaning weight (Figure 5) was seen in the increased number of lambs sold prime at weaning (Table 2). However, the final importance of this variation is not realised until lamb finishing over the subsequent summer and autumn periods is taken into account. This response varies between geo-climatic regions.

\section{Post-weaning impacts in four geo-climatic regions}

Pasture supply and feed quality during the postweaning period has a significant impact on the final outcomes of the early spring grazing strategies investigated. This was demonstrated by the second phase of the modelling which investigated the impacts of two South Island and two North Island hill country feed supply profiles representing four contrasting geoclimatic regions of New Zealand (Figure 1).

Across all four geo-climatic regions using the Lax (low stocking rate) grazing strategy, regardless of starting cover (Table 2), resulted in an average days to slaughter of 14-18 days post-weaning. Carcase weight 


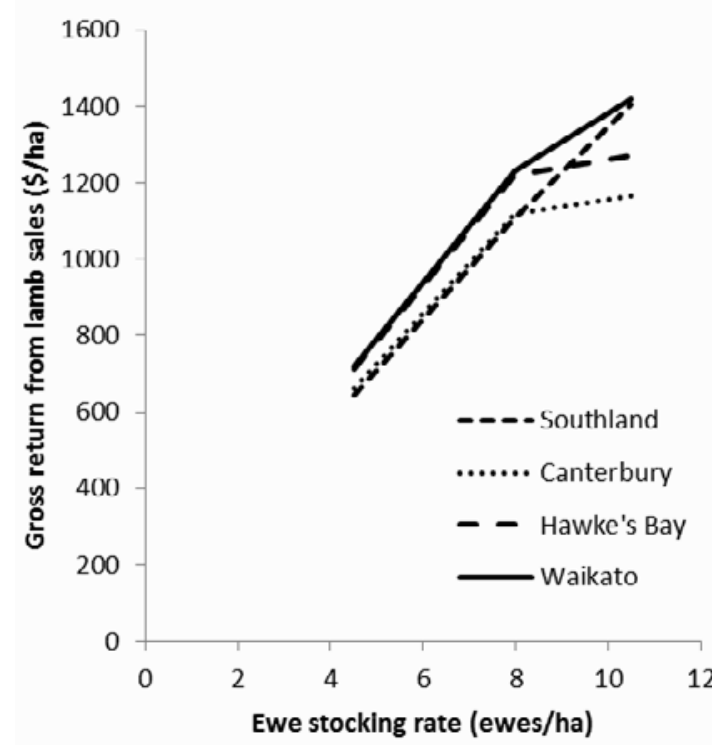

Figure 6 The response of gross returns from lamb sales to increasing ewe stocking rate during spring in four geo-climatic regions of New Zealand when the pasture cover at the start of lambing was $1200 \mathrm{~kg}$ $\mathrm{DM} / \mathrm{ha}$.

averaged approximately $18 \mathrm{~kg}$ and all lambs were sold prime (Table 2). The amount of pasture eaten was also very similar at $62-66 \mathrm{~kg} \mathrm{DM} / \mathrm{ha}$. However, the total gross revenue returns from lamb sales increased with earlier lambing date because of a higher early lamb price, resulting in Waikato receiving approximately $\$ 80$ /ha more than Southland (Table 2).

The pasture cover at the start of lambing had relatively little impact on lamb production when using the Moderate (medium stocking rate) grazing strategy (Table 2; Figures 6 and 7). While the days to slaughter increased to between 23-36 days post-weaning and the amount of pasture eaten increased to between 279-385 $\mathrm{kg} \mathrm{DM} / \mathrm{ha}$, all lambs (except at a starting pasture cover of $1500 \mathrm{~kg} \mathrm{DM} / \mathrm{ha}$ in Hawke's Bay) were sold prime (Table 2). The gross revenue from lamb sales was relatively similar across all the regions, ranging from $\$ 1102 /$ ha to $\$ 1229 /$ ha (Figure 6), with the North Island regions having slightly higher income due to an earlier slaughter date (Table 2).

At a low starting pasture cover of $1200 \mathrm{~kg} \mathrm{DM} / \mathrm{ha}$, the gross revenue from lamb sales increased markedly when going from a stocking rate of 4.5 to 10.5 ewes/ha in both Southland and Waikato (Figure 6). Similarly, the gross revenue significantly increased in Canterbury and Hawke's Bay when the stocking rate was increased from 4.5 to 8 ewes/ha. However, increasing the stocking rate even further to 10.5 ewes/ha in these latter two regions did not generate the same additional gains

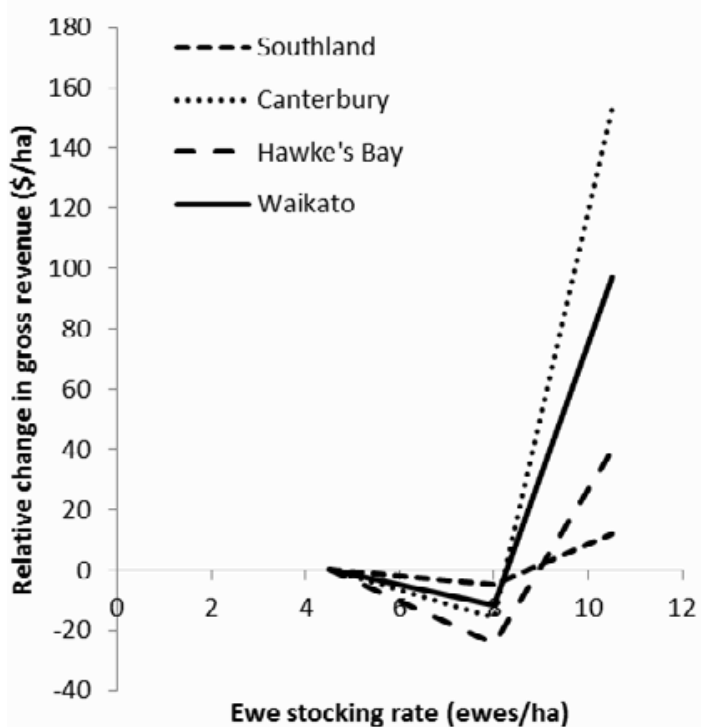

Figure 7

Change in gross revenue from lamb sales when the pasture cover at the start of lactation is increased from 1200 (see Figure 6) to $1500 \mathrm{~kg} \mathrm{DM} / \mathrm{ha}$ in four geo-climatic regions of New Zealand.

as was achieved in Southland and Waikato (Figure 6). Figure 7 reports the marginal change in revenue when the higher pasture-cover of $1500 \mathrm{~kg} \mathrm{DM} / \mathrm{ha}$ was available at the start of lambing. At a higher starting cover, lamb income sales increased when the stocking rate was increased from 8 to 10.5 ewes/ha especially in Canterbury and to a lesser extent in the Waikato, with a limited increase in Hawke's Bay and basically no increase in Southland.

Between region variation in the relative increase in gross revenue due to the higher pasture cover at the start of lactation were greatest when stocking rate was high (Figure 7). This reflected the relative availability of pasture for lamb finishing. In Southland, both feed quantity and quality remained high post-weaning owing to the climate (Figure 1), enabling all lambs to be finished prime regardless of their weaning weight, whereas in the other regions, the pasture resources were more constrained. In Canterbury the constraint was feed supply, while in Waikato it was feed quality (Figure 1). In both instances, these limitations are ameliorated by the reduction in resources required for finishing through the higher lamb weaning weight that result from a higher pasture cover $(1500 \mathrm{~kg} \mathrm{DM} / \mathrm{ha})$ at the start of lactation. In Hawke's Bay the restrictions imposed by summer and autumn feed supply are unable to be ameliorated by the higher weaning weight, and therefore no significant change in income can be generated from the higher pasture cover at the start of lactation. 
The amount of feed required to achieve the final gross revenue outcomes under a high stocking rate were between 535 and $1441 \mathrm{~kg} \mathrm{DM} / \mathrm{ha}$ (Table 2). This reflected the pasture availability and the pasture quality in each region (Figure 1). Pasture availability was least in Hawke's Bay and so more lambs were sold store as the amount of pasture available for finishing was restricted by pasture growth rate in summer and autumn. Pasture quality was greatest in Southland, resulting in less pasture eaten to meet slaughter weight requirements due to higher lamb growth rates (Figure 1). More pasture was eaten in the Low starting cover (1200 kg DM/ha) scenarios due to the lower weaning weight. The exception was the Hawke's Bay, where summer pasture availability reduced the opportunity for lamb finishing.

The greater amount of pasture required to finish lambs under the Intense grazing (high stocking rate) strategy was a direct result of lower weaning weights and demonstrates the importance of early spring pasture conditions and grazing strategies on lamb finishing in hill country. The amount of feed required in the postweaning period to finish lambs under the Lax grazing (low stocking rate) strategy was $10 \mathrm{~kg} \mathrm{DM} / \mathrm{lamb}$ sold, while under the Moderate grazing (medium stocking rate) strategy this was $28 \mathrm{~kg} \mathrm{DM} / \mathrm{lamb}$ sold. Under the Intense grazing (high stocking rate) strategy this increased to $67 \mathrm{~kg} \mathrm{DM} / \mathrm{lamb}$ sold, and not all lambs were able to be sold prime. The net increase in $39 \mathrm{~kg}$ $\mathrm{DM} / \mathrm{lamb}$ required for finishing resulted from both less lambs being sold at weaning and a longer time being required to reach slaughter weight. When the stocking rate was high this was alleviated by starting lactation with a higher pasture cover which resulted in a higher lamb weaning weight which in turn reduced the extra feed requirement by $10 \mathrm{~kg} \mathrm{DM} / \mathrm{lamb}$ finished. On a per hectare basis the high stocking rate used an extra $675 \mathrm{~kg} \mathrm{DM} / \mathrm{ha}$ attempting to finish lambs. Much of this was attributed to the lower weaning weight of those lambs. This extra feed requirement may represent an opportunity cost that farmers could capture in other enterprises if appropriate early spring grazing strategies were chosen.

\section{Conclusions}

This computer simulation-modelling study demonstrates that the grazing strategies used in early spring (i.e. start of lambing) can have a significant impact on the subsequent finishing of lambs in hill country. The strategies modelled markedly influenced lamb and ewe liveweights at weaning. The flow-on effects from these variations were different in the four contrasting geo-climatic regions studied. In the Southland region with wet/cool summer conditions, high year-round feed quality and adequate pasture growth enabled all lambs to be finished prime regardless of the starting pasture covers at lambing, even though much more feed was required when lamb weaning weight was reduced by some of the early spring grazing strategies used. In the Hawke's Bay and Canterbury regions with dry/hot summer conditions and associated restricted pasture growth, high stocking rates only provided extra gross revenue from lamb sales when a high prelambing starting pasture cover was used. However, in the Waikato region with wet/hot summer conditions and adequate pasture growth, a high stocking rate provided moderate extra returns when starting pasture cover was low, but even greater returns when starting pasture cover was high. In all of the regions studied, any reduction in lamb weaning weight resulted in more pasture being needed to finish lambs during the summer and autumn and would represented an opportunity cost for farmers.

The potential for ewe liveweight changes to support lactation was highlighted as a subject that requires more research to investigate how small time scale changes in body weight might affect lactation. The modelling of the grazing strategies chosen suggests that more research is needed to understand the actual feeding and liveweight change dynamics of ewes over the critical early spring/lactation period.

The availability of pasture and ewe body reserves appeared to be adequate under the assumptions made in this study to support high lamb liveweight gain until mid to late lactation. Variations in lamb weaning weight were likely to be a result of late lactation variations in pasture supply. This provides a focus for farmers attempting to increase weaning weight.

\section{ACKNOWLEDGEMENTS}

Funding from Ministry of Business, Innovation and Employment, DairyNZ, Fonterra, Beef + Lamb New Zealand and DCANZ; advice on farmer needs from Beef + Lamb New Zealand.

\section{REFERENCES}

Agricultural and Food Research Council. 1993. Energy and protein requirements of ruminants. $\mathrm{CAB}$ International, Wallingford. $159 \mathrm{pp}$.

Casey, M.J.; Scandrett, J.S.; Stevens, D.R. 2013. Ewe body condition score: Does farmer practice meet research guidelines? pp. 1882-1883. In: Proceedings of the 22nd International Grassland Congress. Sydney, Australia.

Corner-Thomas, R.A.; Hickson, R.E.; Morris, S.T.; Back, P.J.; Ridler, A.L.; Stafford, K.J.; Kenyon, P.R. 2015. Effects of body condition score and nutrition in lactation on twin-bearing ewe and lamb performance to weaning. New Zealand Journal of Agricultural Research 58: 156-169. 
Danckwerts, J.E.; Tainton, N.M. 1993. Range management - optimising forage production and quality. pp. 843-850. In: Proceedings of the 17 th International Grassland Congress. New Zealand Grassland Association, New Zealand.

Everett-Hincks, J.M.; Stevens, D.R.; Rendel, J.M.; Smith, T.R.; Smith, P.J. 2013. The effect of ewe prelamb body condition on triplet lamb performance in a commercial flock. Proceedings of the New Zealand Society of Animal Production 73: 126-130.

Geenty, K.G.; Sykes, A.R. 1986. Effect of herbage allowance during pregnancy and lactation on feed intake, milk production, body composition and energy utilisation of ewes at pasture. Journal of Agricultural Science, Cambridge. 106: 351-367.

Hodgson, J.; Wade, M.H. 1978. Grazing management and herbage production. pp. 1.1-1.11. In: Grazing, sward production and livestock output. British Grassland Society, winter meeting,

Keating, B.A.; Carberry, P.S.; Hammer, G.L.; Probert, M.E.; Robertson, M.J.; Holzworth, D.; Huth, N.I.; Hargreaves, J.N.G.; Meinke, H.; Hochman, Z.; McLean, G.; Verburg, K.; Snow, V.; Dimes, J.P.; Silburn, M.; Wang, E.; Brown, S.; Bristow, K.L.; Asseng, S.; Chapman, S.; McCown, R.L.; Freebairn, D.M.; Smith, C.J. 2003. An overview of APSIM, a model designed for farming systems simulation. European Journal of Agronomy 18: 267-288.

Kenyon, P.R.; Morel, P.C.H.; Morris, S.T. 2004. Effect of liveweight and condition score of ewes at mating, and shearing mid-pregnancy, on birthweights and growth rates of twin lambs to weaning. New Zealand Veterinary Journal 52: 145-149.

Li, F.Y.; Vibart, R.; Dynes, R.A.; Vogeler, I.; Brown, M. 2012. Effects of weather variability on sheep and beef farming in Northern Southland, New Zealand: A modelling analysis. Proceedings of the New Zealand Grassland Association 74: 77-84.

Litherland, A.J.; Lambert, M.G.; McLaren, P.N. 1999. Effects of herbage mass and ewe condition score at lambing on lamb survival and liveweight gain. Proceedings of the New Zealand Society of Animal Production 59: 104-107.

Litherland, A.J.; Woodward, S.J.R.; Stevens, D.R.; McDougal, D.B.; Boom, C.J.; Knight, T.L.; Lambert, M.G. 2002. Seasonal variations in pasture quality on New Zealand sheep and beef farms. Proceedings of the New Zealand Society of Animal Production 62: 138-142.

McCall, D.G.; Smeaton, D.C.; Wadams, T.K.; Gibbison, M.L.; Hockey, H.-U.P. 1986. Lambing date, ewe live weight and pasture mass effects on ewe and lamb performance during lactation. Proceedingsof the New Zealand Society of Animal Production 46: 129-132.
Moss, R.A.; Dynes, R.A.; Goulter, C.L.; Saville, D.J. 2009. Forward creep grazing of lambs to increase liveweight gain and post-weaning resistance to endoparasites. New Zealand Journal of Agricultural Research 52: 399-406.

Muir, P.D.; Smith, N.B.; Wallace, G.J.; Fugle, C.J.; Bown, M.D. 2000. Maximising lamb growth rates. Proceedings of the New Zealand Grassland Association 62: 55-58.

Muir, P.D.; Smith, N.B.; Lane, J.C. 2003. Maximising lamb growth rate - just what is possible in a high performance system. Proceedings of the New Zealand Grassland Association 65: 61-63.

Parker, W.J.; Shadbolt, N.M.; Gray, D.I. 1997. Strategic planning in grassland farming: Principles and applications. Proceedings of the New Zealand Grassland Association 59: 191-197.

Radcliffe, J.E. 1975. Seasonal distribution of pasture production in New Zealand. VII. Masterton (Wairarapa) and Maraekakaho (Hawke's Bay). New Zealand Journal of Experimental Agriculture 3: 259265.

Rattray, P.V.; Jagusch, K.T.; Duganzich, D.M.; MacLean, K.S.; Lynch, R.J. 1982. Influence of feeding post-lambing on ewe and lamb performance at grazing. Proceedings of the New Zealand Society of Animal Production 42: 179-182.

Rattray, P.V.; Thompson, K.F.; Hawker, H.; Sumner, R.M.W. 1987. Pastures for sheep production. pp. 89103. In: Livestock feeding on pastures. Ed. Nicol, A. M. New Zealand Society of Animal Production, Hamilton.

Rickard, D.S.; Radcliffe, J.E. 1976. Seasonal distribution of pasture production in New Zealand. XII. Winchmore, Canterbury Plains dryland and irrigated pastures. New Zealand Journal of Experimental Agriculture 4: 329-335.

Round-Turner, N.L.; Scott, R.S.; Racliffe, J.E. 1976. Seasonal distribution of pasture production in New Zealand. XI. Otago downland and Taieri Plain (Invermay). New Zealand Journal of Experimental Agriculture 4: 321-328.

Sithamparanathan, J. 1979. Seasonal growth patterns of herbage species on high rainfall hill country in northern North Island. I Temperate grasses. New Zealand Journal of Experimental Agriculture 7: 157162.

Smeaton, D.C.; Rattray, P.V. 1984. Winter-spring nutrition and management effects on ewe and lamb performance. Proceedings of the New Zealand Grassland Association 45: 190-198.

Stevens, D.R.; Casey, M.J.; Scandrett, J.S.; Baxter, G.S. 2011. Winter feeding - changing labour requirement and productivity. Proceedings of the New Zealand Grassland Association 73: 51-56. 
Stevens, D.R.; Thompson, B.R.; Carruthers, A.; Wall, A.J.; Casey, M.J.; Phiskie, R.; Young, P.; Moot, D.J. 2012. Understanding the role of spring grazing of lucerne in the Central Otago environment. Proceedings of the New Zealand Grassland Association 74: 69-76.

Stevens, D.R.; Wall, A.J.; Thompson, B.R.; O’Neill, K.T.; Scott, I.C. 2013. The dilemma of using sward height as a management tool for intensively grazed sheep pasture in spring. pp. 1095-1096. In: Proceedings of the 22nd International Grassland Congress Sydney, Australia.

Stevens, D.R.; Wright, L.; McGill, P. 2015. An on-farm study of late pregnancy and lactation performance of yearling ewes and their progeny on lucerne or pasture. Journal of New Zealand Grasslands 77: 269-274.

Thompson, B.R. 2014. Will the New Zealand deer industry remain competitively profitable in the future? Masterate Thesis, Lincoln University. https://researcharchive.lincoln.ac.nz/ handle/10182/6424.

Thompson, K.F.; Sedcole, J.R.; O'Connell, D.; Geenty, K.G.; Sykes, A.R. 1990. Spring and summer pasture feeding and ewe reproduction and wool growth. Proceedings of the New Zealand Grassland Association 52: 123-127.

Woodward, S.J.R.; Lambert, M.G.; Litherland, A.J.; Boom, C.J. 2001. Can a mathematical model accurately predict intake of grazing animals? Testing the Q-Graze model. Proceedings of the New Zealand Society of Animal Production 61: 4-7.

Woodward, S.J.R.; Webby, R.W.; Johnstone, L.J.C. 2000. A decision tool for calculating herbage mass and metabolisable energy requirements of growing cattle and sheep. Proceedings of the New Zealand Grassland Association 62: 13-18. 